\title{
Turning the Tide on Chronic Disease: How a Province Is Using Evidence to Build Quality Improvement Capacity
}

Renverser le courant des maladies chroniques :
le cas d'une province utilisant des données
probantes pour renforcer la capacité en
matière d'amélioration de la qualité

by CANADIAN HEALTH SERVICES RESEARCH FOUNDATION

\begin{abstract}
Saskatchewan's Chronic Disease Management Collaborative is a quality improvement model that brings together healthcare providers to learn about, test and share experiences with improvement ideas in diabetes and coronary artery disease care. This innovative initiative was recently featured in Promising Practices, a monthly series produced by the Canadian Health Services Research Foundation highlighting organizations that have invested their time, energy and resources to try to improve their ability to use research in the delivery of health services. The Promising Practices inventory can be found at www.chsrf.ca/promising/index_e.php.
\end{abstract}




\section{Résumé}

Linitiative Chronic Disease Management Collaborative de la Saskatchewan est un modèle visant à améliorer la qualité qui rassemble les fournisseurs de services de santé pour apprendre et mettre à l'essai des idées ainsi que partager leur expérience en vue d'améliorer les soins offerts aux patients atteints du diabète ou de coronaropathie. Cette initiative novatrice a fait l'objet d'un article dans Pratiques prometteuses, une série mensuelle produite par la Fondation canadienne de la recherche sur les services de santé, qui présente des organismes ayant investi temps, argent et ressources afin d'améliorer leurs capacités à utiliser la recherche dans la prestation des services de santé. La liste des numéros de la série Pratiques prometteuses se trouve à : http://www. chsrf.ca/pratiques/index_f.php.

$\mathrm{I}$ N November 2005, Saskatchewan embarked ON its largest healthcare quality improvement initiative to date. How big is big? The Saskatchewan Chronic Disease Management Collaborative involves:

- 28 percent of the provincés family physicians and about 30 percent of its primary care practices;

+ more than 600 health professionals;

+ all 13 of Saskatchewan's health regions; and

- more than 14,000 people living with diabetes and coronary artery disease.

The collaborative aims to improve the care and health of residents living with these diseases, as well as access to care. It is sponsored by the province's Health Quality Council, an independent agency that not only measures and reports on quality of care but also takes action to promote quality improvement.

Council research showed that less than half of those with diabetes were meeting recommended targets for blood sugar and blood pressure levels and that many heart attack patients did not receive key medications proven to prevent second heart attacks and save lives.

"The evidence on optimal diabetes and coronary artery disease care is well known," says Karen Barber, the council's director of quality improvement, "so it's not the 'what to do' that healthcare professionals struggle with. Their challenge is how to do it in routine practice."

Helping with how to do it is what the Chronic Disease Management Collaborative is all about. A collaborative is an improvement method that spreads existing knowledge to multiple settings. Key features include learning quality improve- 
ment techniques, sharing "on-the-ground" experiences and conducting small tests of change known as plan-do-study-act cycles.

Participants in the Chronic Disease Management Collaborative - doctors and other healthcare professionals - work in teams, meeting in workshops where they discuss new ideas for improving care. Once back in their care settings, they test these and their own ideas and share their experiences with other team members.

\section{Key Messages}

- Saskatchewan's Chronic Disease Management Collaborative is a quality improvement model that brings together healthcare providers to learn about, test and share experiences with improvement ideas in diabetes and coronary artery disease care.

- A web-based toolkit tracks and helps manage patient care, allows all of a patient's care providers to share information and creates reports documenting care improvement and identifying gaps.

- People with diabetes and coronary artery disease are demonstrably receiving better care.

- The model can be used to improve quality in other care areas.

The use of technology to better manage patient care is another key feature. Participants track patient progress via the Chronic Disease Management Toolkit, a web-based disease registry and support tool originally developed in British Columbia. It tracks a patient's care and reminds care providers of required tests, services or medications. It allows all of a patient's care providers to share information and creates reports documenting care improvement and identifying gaps.

"For providers, there's a difference between thinking they are providing good care and knowing it," says Bonnie Brossart, the council's interim CEO."With the toolkit, they can see at a glance how their patients are doing. They can also see which practices are doing well in a particular area and find out if there's something to learn from them."

Positive changes in diabetes and coronary artery disease care have already been seen among collaborative participants. Access is improving, with almost 85 percent of patients being seen on their day of choice. As well, more patients are receiving the recommended drugs and services for their condition:

- among patients with diabetes, 25 percent more have had a urine microalbumin screening test and 10 percent more have been prescribed a drug to help control blood cholesterol levels; and 
- 85 percent of patients with coronary artery disease have been prescribed antiplatelet therapy, 11 percent more than when the collaborative began.

Early results are also showing positive trends:

- about 700 more patients with diabetes have achieved good control of their blood sugar, a five-percent improvement; and

- three percent more coronary artery disease patients have reached a healthy blood pressure level.

"Though we're not completely there yet, these initial results are encouraging," says Ms. Barber."Even more encouraging are the many requests we've had to use the collaborative model in other areas. We're now considering how and when we might do that."

"It's exciting to be part of an organization that doesn't just point out the evidence about what's wrong or needs improvement, but can also help promote positive change," adds Ms. Brossart.

"Participants now have the tools and skills they need to continue making quality improvements, not only in diabetes and heart disease, but in other care areas as well."

\section{Listen and learn.}

Longwoods Radio available now at www.longwoods.com

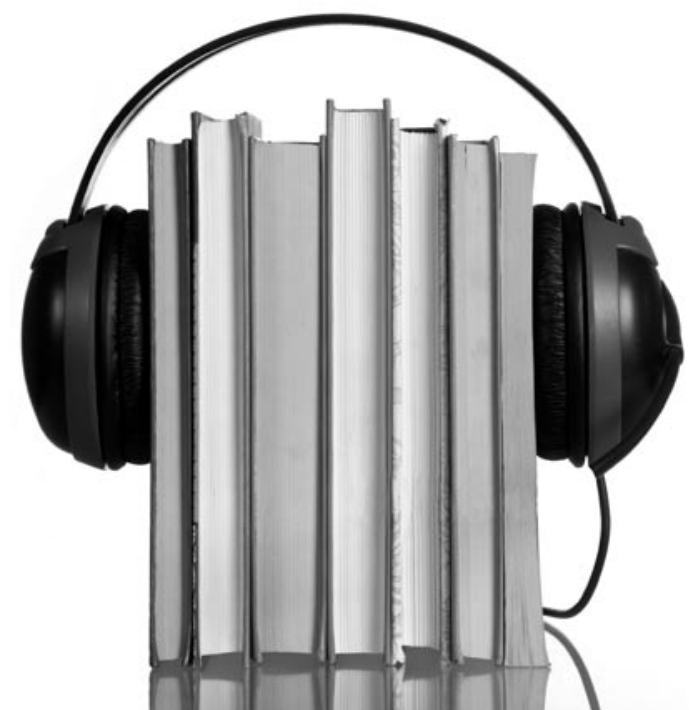

